MICHAŁ MURASZKO

Archiwum Archidiecezjalne w Gnieźnie

\title{
Wycisk plakiety z popiersiem ostatniego Jagiellona na oprawie Commentarius brevis rerum in orbe gestarum ze zbiorów dawnej Biblioteki Katedralnej w Gnieźnie
}

STRESzCzenie. Komunikat prezentuje oprawę kolońskiego druku z 1568 roku. Zwierciadło jej dolnej okładziny zdobi wycisk plakiety z popiersiem króla Zygmunta II Augusta. Literatura przedmiotu podaje kilka przykładów egzemplarzy opraw ozdobionych być może za pomocą tego samego narzędzia introligatorskiego.

SŁowA KLuczowe: Zygmunt II August, Archiwum Archidiecezjalne w Gnieźnie, Biblioteka Katedralna w Gnieźnie, oprawy, tegumentologia.

Przedmiotem niniejszego komunikatu jest oprawa zabezpieczająca druk Commentarius brevis rerum in orbe gestarum wydany w 1568 roku w kolońskiej oficynie Gerwina Caleniusa i dziedziców Jana Quentela1. $\mathrm{Na}$ wolumin natrafiono $\mathrm{w}$ trakcie prac prowadzonych $\mathrm{w}$ ramach projektu „Inwentaryzacja zasobu Biblioteki Katedralnej w Gnieźnie”, którym kieruje dr Piotr Pokora (Uniwersytet im. Adama Mickiewicza w Poznaniu) ${ }^{2}$. Zwierciadło dolnej okładziny prezentowanej oprawy zdobi wycisk owalnej plakiety z popiersiem polskiego króla i wielkiego księcia litewskiego Zygmunta II Augusta (zm. 1572). Literatura przedmiotu odnotowuje

${ }^{1}$ Archiwum Archidiecezjalne w Gnieźnie [dalej: AAG], sygn. BK514; P. Pokora, M. Muraszko, Skarby drukarstwa i introligatorstwa ze zbiorów dawnej Biblioteki Katedralnej w Gnieźnie. Katalog wystawy w Bibliotece Raczyńskich, Poznań 5-30 maja 2015, Poznań-Gniezno 2015, s. 12.

2 Projekt grantowy „Inwentaryzacja zasobu Biblioteki Katedralnej w Gnieźnie” finansowany jest z Narodowego Programu Rozwoju Humanistyki MNiSW (nr: $11 \mathrm{H}$ $12017981)$. 
kilka egzemplarzy opraw, które udekorowano być może przy użyciu tego samego narzędzia introligatorskiego ${ }^{3}$. Założenie to będzie $\mathrm{w}$ przyszłości wymagało weryfikacji przez między innymi zestawienie ze sobą makrofotografii poszczególnych wycisków.

Wyobrażenie popiersia ostatniego Jagiellona zdobi wolumin przechowywany obecnie w Bibliotece Gdańskiej PAN. Został on szczegółowo omówiony w artykułach Zbigniewa Nowaka i Hanny Widackiej. $\mathrm{O}$ dwóch innych tak udekorowanych oprawach, znajdujących się obecnie w Bibliotece Książąt Czartoryskich w Krakowie, wspomina Maria Jarosławiecka-Gąsiorowska ${ }^{5}$. Z rozprawy Alodii Kaweckiej-Gryczowej można natomiast wywnioskować, że omawiane wyciski umieszczono również na egzemplarzach pochodzących z Biblioteki Uniwersytetu Warszawskiego oraz Książnicy Kopernikańskiej w Toruniu ${ }^{6}$. Reprodukcje przedstawień monarchy pojawiają się między innymi w opracowaniach Karola Hartleba ${ }^{7}$ i Edmundasa Laucevičiusa. Ten ostatni informuje, że oprawy z prezentowanym motywem można znaleźć w Bibliotece Uniwersytetu Jagiellońskiego i Bibliotece Książąt Czartoryskich w Krakowie - egzemplarz ten wymienia także Maria Jarosławiecka-Gąsiorowska ${ }^{8}$. Jeden wolumin, według Stena G. Lindberga, znajduje się w Skokloster?.

${ }^{3}$ Wzmiankowany przez Konrada Haeblera (Rollen- und Plattenstempel des XVI. Jahrhunderts..., t. 2, Leipzig 1929, s. 76) wycisk plakiety z popiersiem monarchy oraz dewizą ma mieć kształt koła o średnicy $75 \mathrm{~mm}$.

${ }^{4}$ Z. Nowak, Gdańskie ślady księgozbiorów znakomitych bibliofilów polskich doby Odrodzenia, "Roczniki Biblioteczne” 1983, t. 27, z. 1-2, s. 25-30; H. Widacka, Portrety Zygmunta II Augusta na plakietach introligatorskich XVI wieku, "Kronika Zamkowa” 2013, t. 65-66, nr 1-2, s. 5-14.

${ }^{5}$ Por. M. Jarosławiecka-Gąsiorowska, Ikonografia świecka na oprawach XVI i XVII w., „Rocznik Biblioteki Narodowej” 1970, t. 6, s. 319 oraz ryc. 1.

${ }^{6}$ A. Kawecka-Gryczowa, Biblioteka ostatniego Jagiellona. Pomnik kultury renesansowej, Wrocław 1988, s. 98, p. 38.

${ }^{7}$ K. Hartleb, Biblioteka Zygmunta Augusta. Studium z dziejów kultury królewskiego dworu, Lwów 1928, ryc. po s. 118 (wolumin ten przed II wojną światową miał należeć do zbiorów Muzeum Lubomirskich we Lwowie); por. S. Dahl, Dzieje ksiażki. Pierwsze wydanie polskie, znacznie rozszerzone, przeł. E. Garbacik et al., Wrocław 1965, s. 193, ryc. 48 .

${ }^{8}$ E. Laucevičius, XV-XVIII a. knygu irišimai Lietuvos bibliotekose, Vilnius 1976, s. 117 , nr 597.

9 S.G. Lindberg, Reliures polonaises dans les bibliotheques suedoises de l'age gothique, de la Renaissance et de la Reforme, w: VIIIe Congres international des bibliophiles. Varsovie, 23-29 juillet 1973, red. K. Dymkowska, J. Pasztaleniec-Jarzyńska, Varsovie 1985, s. 109. 
Jak podaje Hanna Widacka, wzór dla twórcy omawianego narzędzia introligatorskiego miał stanowić miedzioryt, pochodzący z około 1553 roku, autorstwa niderlandzkiego sztycharza Cornelisa Corta ${ }^{10}$.

Oprawa, będąca przedmiotem niniejszych rozważań, została sporządzona $z$ fazowanych desek dębowych lub bukowych, które obciągnięto brązową skórą i zaopatrzono $\mathrm{w}$ zapinki mosiężno-skórzane. Zdobienia okładzin opracowano $\mathrm{w}$ technice złoconego i ślepego wycisku, używając strychulca, dwóch plakiet oraz tłoków floralnych i literniczych. Przy użyciu pierwszego z tych narzędzi wykonano ramy, składające się z koncentrycznych linii, które tworzą szerokie zwierciadła górnej i dolnej okładziny. Na ich narożnikach znajdują się wyciski z niewielkiego tłoka o motywie floralnym. Powierzchnia zwierciadła górnej okładziny (il. 1) została pomniejszona, przez umieszczenie w jego górnej strefie dwóch równoległych linii strychulcowych, ponad którymi wyciśnięto antykwowy napis: „CRONICA SVRII". W centrum zwierciadła wkomponowano owalny wycisk plakiety z popiersiem Chrystusa Salwatora $(75 \times 66 \mathrm{~mm})^{11}$. Całości dopełniają wyciski o motywach floralnych, które sporządzono za pomocą tłoków. Niemal analogicznie przyozdobiono okładzinę dolną (il. 2), przy czym zrezygnowano z wydzielonej strefy zawierającej napis, a wycisk owalnej plakiety $(76 \times 68 \mathrm{~mm})$ przedstawia popiersie Zygmunta II Augusta zwrócone 3/4 w lewo (od strony patrzącego). Władca, z długą broda, odziany jest w ozdobne szaty z futrzanym kołnierzem i kołpak (il. 3). Całość przedstawienia okala pierścień z wkomponowanym weń antykwowym napisem: „SIGISMVNDVS AVG REX POLONIAE MAGNVS DVX LITVA RVSSI MASONIAE PRVSS AC SAMAGITIAE C. D. ET HAER". Wymiary wycisku, jak też błędy pojawiające się w wyrazach "Masoviae" oraz "Samogitiae" zdają się dowodzić, że wykonano go narzędziem, którym udekorowano przynajmniej część z wymienionych wcześniej innych egzemplarzy ${ }^{12}$. Grzbiet oprawy, na którym zaznaczono pięć garbów zwięzów i kapitałki, zdobią wyciski tłoków o motywach floralnych.

${ }^{10}$ H. Widacka, op.cit., s. 9-12 oraz ryc. 5; por. M. Jarosławiecka-Gąsiorowska, op.cit., s. 320; A. Kawecka-Gryczowa, op.cit., s. 98, p. 37; Z. Nowak, op.cit., s. 28, p. 14.

${ }^{11}$ Napis w otoku: „IESVS CHRISTVS FILIVS DEI VIVI SALVATOR MVNDI REX REGVM DOMINVS DOMI".

${ }^{12} \mathrm{~W}$ tle przedstawienia znanego z opracowania Karola Hartleba znajdują się wyobrażenia kilkudziesięciu gwiazdek. Można przypuszczać, że nie pochodzą one z plakiety, ale z tłoków, których introligator użył po wykorzystaniu pierwszego z narzędzi; por. K. Hartleb, op.cit., ryc. po s. 118; Zbigniew Nowak (op.cit., s. 28) oraz zapewne za nim Hanna Widacka (op.cit., s. 13, p. 20) podają że wycisk na oprawie woluminu z Biblioteki Gdańskiej PAN ma wymiary: 75 x $65 \mathrm{~mm}$. 


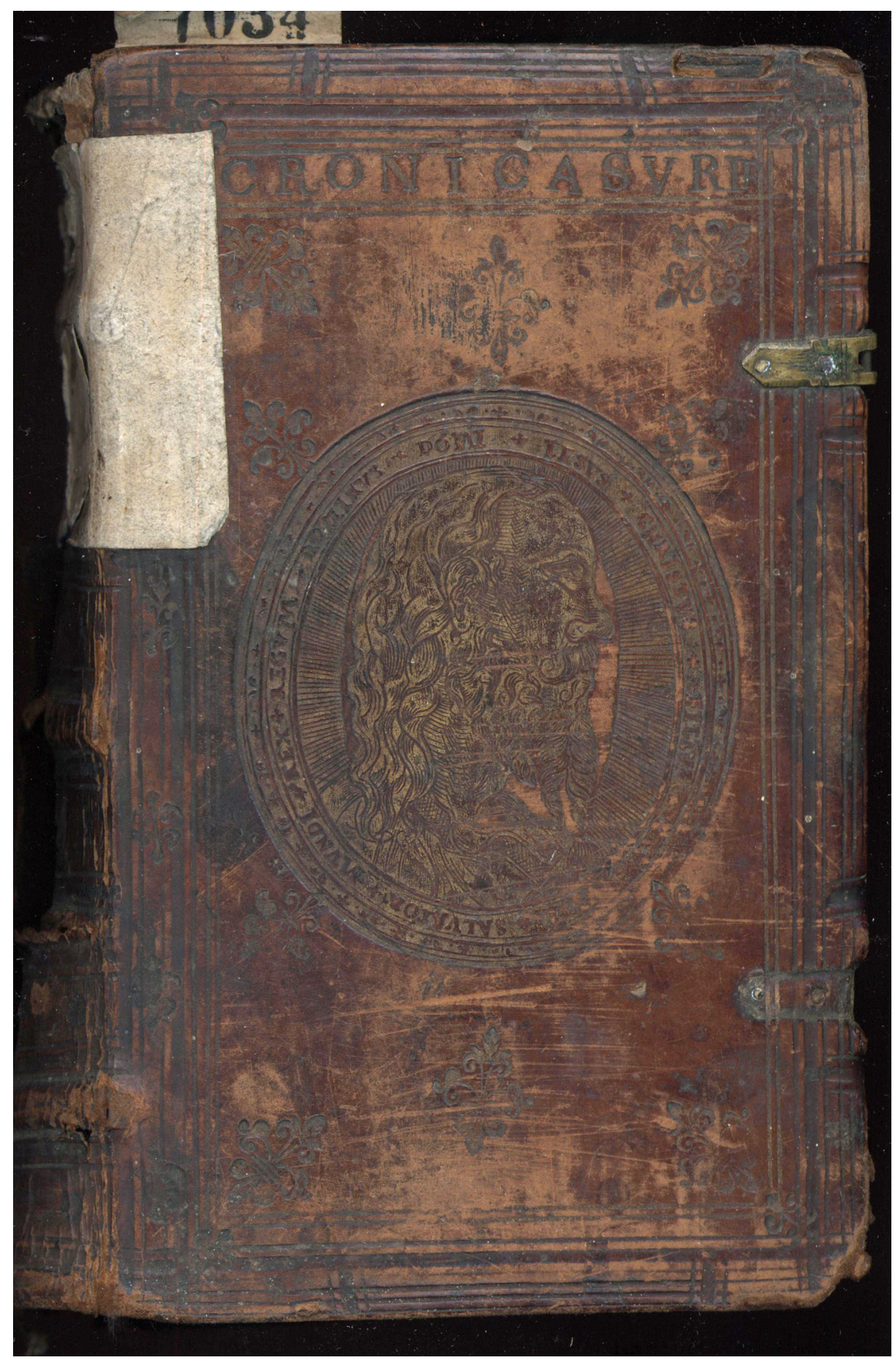

Il. 1. Górna okładzina oprawy kolońskiego druku z 1568 roku Źródło: Archiwum Archidiecezjalne w Gnieźnie, sygn. BK514. Fot. Mikołaj Macioszek. 
Wycisk plakiety z popiersiem ostatniego Jagiellona na oprawie Commentarius brevis 199

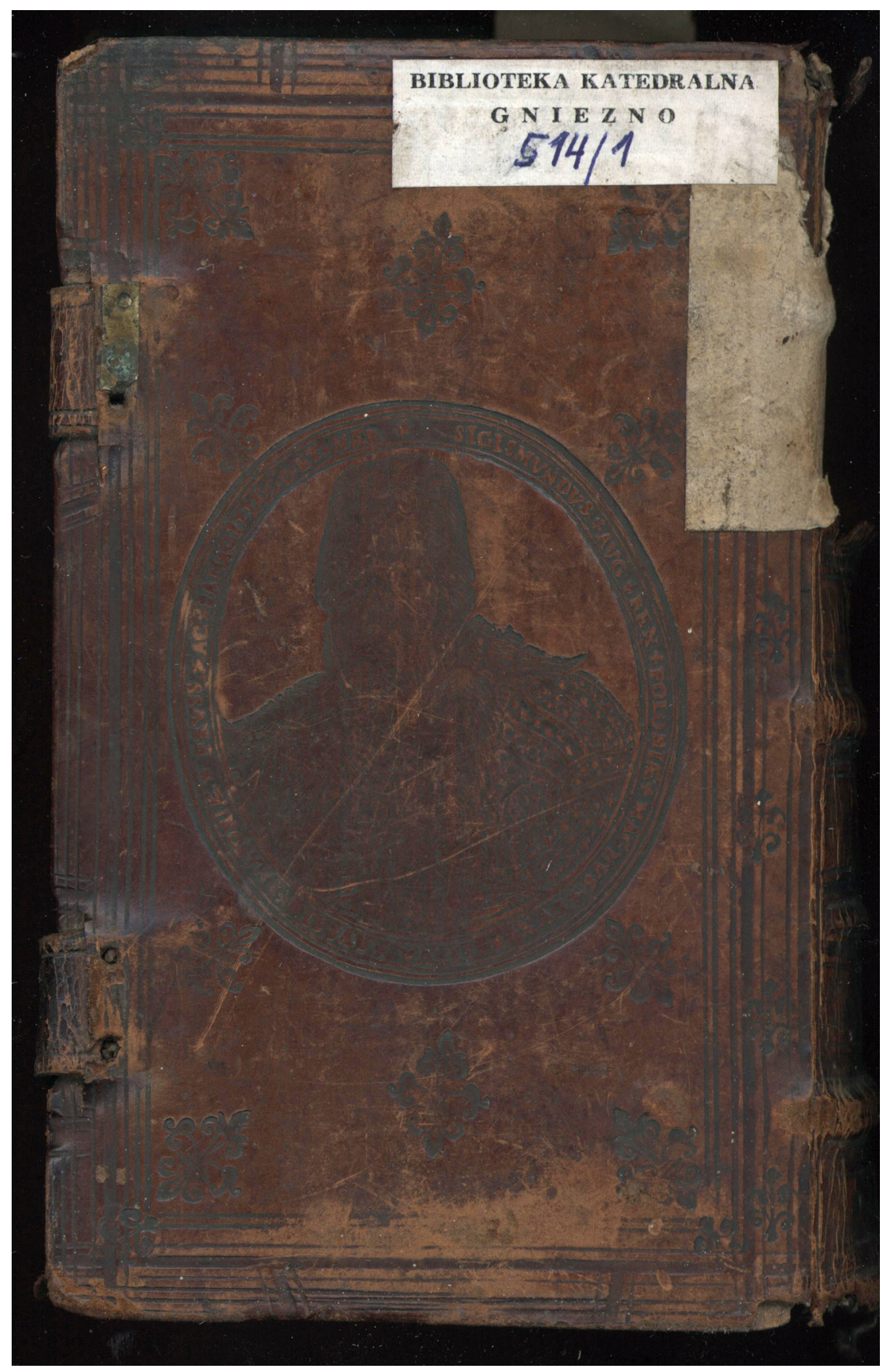

Il. 2. Dolna okładzina oprawy kolońskiego druku z 1568 roku Źródło: Archiwum Archidiecezjalne w Gnieźnie, sygn. BK514. Fot. Mikołaj Macioszek. 
Jako terminus a quo powstania oprawy należy przyjąć rok wydania (1568) kolońskiego druku. Zygmunt II August zmarł w 1572 roku. Omawianą plakietę wykorzystywano jednak również po tej dacie. Przykładem tego jest oprawa przywołanego wyżej krakowskiego druku z 1579 roku znajdującego się w Bibliotece Książąt Czartoryskich w Krakowie ${ }^{13}$.

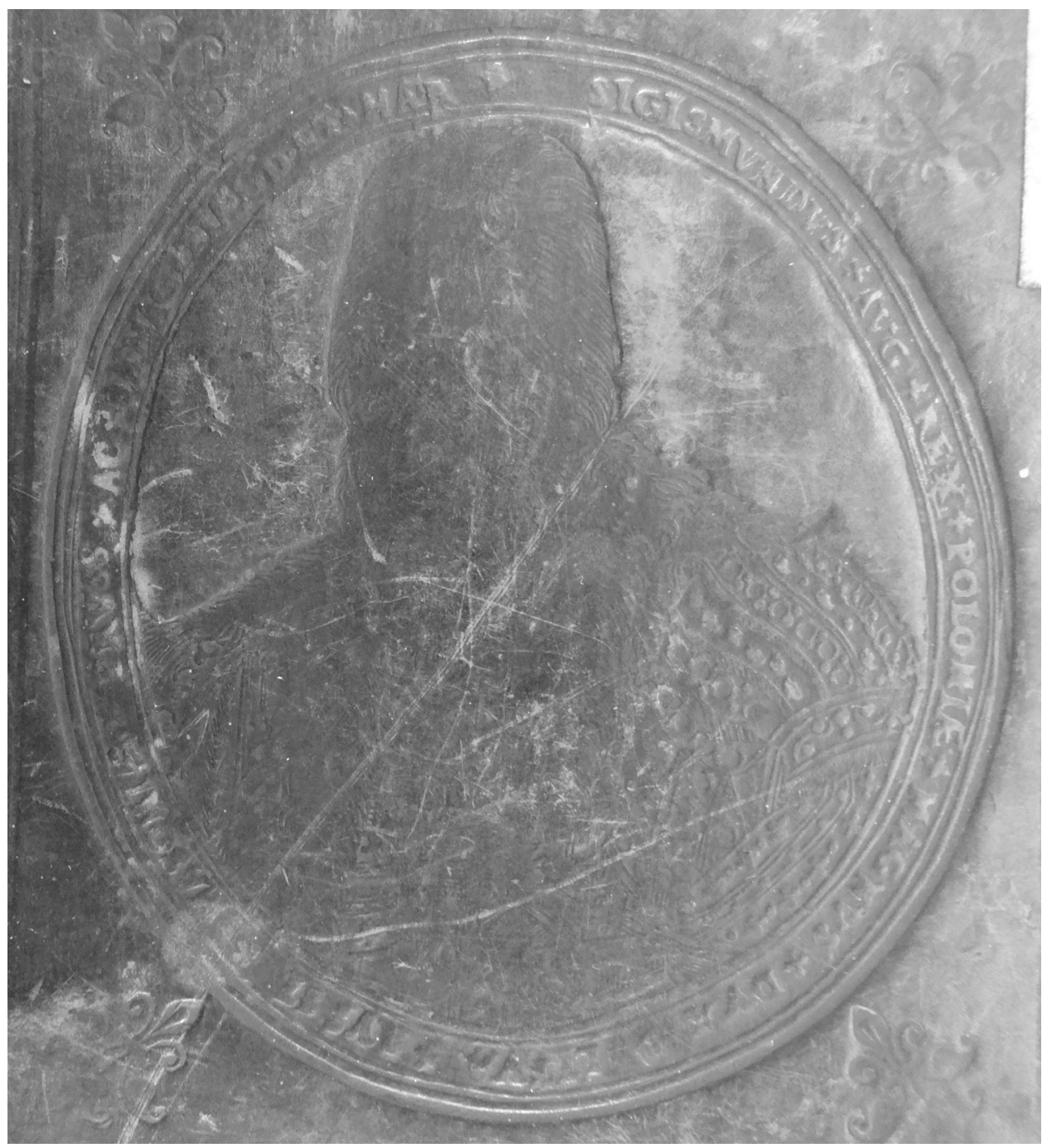

Il. 3. Wycisk plakiety z popiersiem Zygmunta II Augusta - zwierciadło dolnej okładziny oprawy kolońskiego druku z 1568 roku

Źródło: Archiwum Archidiecezjalne w Gnieźnie, sygn. BK514. Fot. Michał Muraszko.

${ }^{13}$ M. Jarosławiecka-Gąsiorowska, op.cit., s. 319. 
Można zatem przyjąć, że gnieźnieński egzemplarz sporządzono jeszcze u schyłku lat 60. XVI wieku lub w ciągu kolejnej dekady tego stulecia.

Przyporządkowanie znaku wodnego z wyklejki oprawy woluminu do konkretnej papierni może przysłużyć się do określenia ośrodka introligatorskiego, z którego pochodzi jego oprawa ${ }^{14}$. Nie jest to możliwe w przypadku omawianej księgi. Obecny tutaj bardzo niewielki fragment filigranu nie pozwala niestety na identyfikację młyna papierniczego. Przyjmuje się, że plakietę z wizerunkiem Jagiellona należy łączyć z jedną z introligatorni krakowskich ${ }^{15}$. Być może zestawienie ze sobą znaków wodnych z wyklejek (o ile te się zachowały) pozostałych woluminów ozdobionych wizerunkiem popiersia monarchy pozwoli w przyszłości na dodatkowe potwierdzenie tego założenia ${ }^{16}$.

Nie sposób obecnie stwierdzić, od jak dawna prezentowana książka stanowi własność Biblioteki Katedralnej w Gnieźnie. Jest ona bowiem pozbawiona jakichkolwiek wpisów czy też pieczątek własnościowych ${ }^{17}$. Należy przy tym odnotować, że wolumin nie został ujęty w katalogu sporządzonym przez ks. Jana Korytkowskiego w 1877 roku $^{18}$.

\section{Bibliografia}

Źródła

Archiwum Archidiecezjalne w Gnieźnie, Katalog Biblioteki Katedralnej w Gnieźnie z $1877 \mathrm{r}$. [bez sygnatury].

Archiwum Archidiecezjalne w Gnieźnie, sygn. BK514.

Biblioteka Gdańska PAN, sygn. 4374/82.

Opracowania

Dahl S., Dzieje ksiażki. Pierwsze wydanie polskie, znacznie rozszerzone, przeł. E. Garbacik et al., Wrocław 1965.

Haebler K., Rollen- und Plattenstempel des XVI. Jahrhunderts..., t. 2, Leipzig 1929.

${ }^{14}$ Por. A. Wagner, Introligatorstwo poznańskie XVI wieku jako historyczno-artystyczna terra incognita, w: Sztuka w Wielkopolsce, red. M. Błaszczyński et al., Poznań 2013, s. 71 .

${ }^{15}$ Por. H. Widacka, op.cit., s. 9; według M. Jarosławieckiej-Gąsiorowskiej (op.cit., s. 320) oprawy ozdobione plakietą z popiersiem monarchy mogły powstać w introligatorni warszawskiej.

${ }^{16}$ Pierwotne wyklejki nie zachowały się co najmniej w przypadku woluminu z Biblioteki Gdańskiej PAN, sygn. 4374/82 (znany autorowi z fotografii).

17 Zachowały się natomiast dawne sygn. woluminu: G. 78[?]; 7034.

18 AAG, Katalog Biblioteki Katedralnej w Gnieźnie z 1877 r. [bez sygnatury]. 
Hartleb K., Biblioteka Zygmunta Augusta. Studium z dziejów kultury królewskiego dworu, Lwów 1928.

Jarosławiecka-Gąsiorowska M., Ikonografia świecka na oprawach XVI i XVII w., „Rocznik Biblioteki Narodowej” 1970, t. 6.

Kawecka-Gryczowa A., Biblioteka ostatniego Jagiellona. Pomnik kultury renesansowej, Wrocław 1988.

Laucevičius E., XV-XVIII a. knygu irišimai Lietuvos bibliotekose, Vilnius 1976.

Lindberg S.G., Reliures polonaises dans les bibliotheques suedoises de l'age gothique, de la Renaissance et de la Reforme, w: VIIIe Congres international des bibliophiles. Varsovie, 23-29 juillet 1973, red. K. Dymkowska, J. Pasztaleniec-Jarzyńska, Varsovie 1985.

Nowak Z., Gdańskie ślady księgozbiorów znakomitych bibliofilów polskich doby Odrodzenia, „Roczniki Biblioteczne” 1983, t. 27, z. 1-2.

Pokora P., Muraszko M., Skarby drukarstwa i introligatorstwa ze zbiorów dawnej Biblioteki Katedralnej w Gnieźnie. Katalog wystawy w Bibliotece Raczyńskich, Poznań 5-30 maja 2015, Poznań-Gniezno 2015.

Wagner A., Introligatorstwo poznańskie XVI wieku jako historyczno-artystyczna terra incognita, w: Sztuka w Wielkopolsce, red. M. Błaszczyński et al., Poznań 2013.

Widacka H., Portrety Zygmunta II Augusta na plakietach introligatorskich XVI wieku, „Kronika Zamkowa” 2013, t. 65-66, nr 1-2.

MICHAє MURASZKO

\title{
The embossed plaquette with a bust length portrait of the last Jagiellonian king inserted in the binding of the "Commentarius brevis rerum in orbe gestarum" from the collection of the former Cathedral Library in Gniezno
}

\begin{abstract}
Aвstract. The communique presents the binding of a printed book published in Cologne in 1568. The lower part of the cover vignette of the book is embellished with a bust of Sigismund August II of Poland embossed in the binding. It should be added at this point that the relevant literature of the subject includes a number of examples of bindings decorated with ornaments that might have been embossed by the same binding device.
\end{abstract}

Key words: Sigismund August II, Gniezno Archdiocese Archives, Cathedral Library in Gniezno, bindings, tegumentology (the knowledge about bindings). 